\title{
Reconstruction of past terrestrial carbon storage in the Northern Hemisphere from the Osnabrück Biosphere Model and palaeodata
}

\author{
C. H. Peng ${ }^{1}$, J. Guiot ${ }^{1}$, E. van Campo ${ }^{2}$ \\ ${ }^{1}$ Laboratoire de Botanique Historique \& Palynologie, UA CNRS 1152, Faculté de St Jérôme, F-13397 Marseille Cedex 20 , France \\ ${ }^{2}$ Laboratoire de Géologie du Quaternaire, CNRS Luminy, F-13288 Marseille Cedex, France
}

\begin{abstract}
Until now the reconstruction of past carbon storage from data has often been done by using modern carbon databases. The results are likely a rough approximation of the reality, and can be improved by the use of biosphere models. These models usually need to be parameterized by a large number of environmental inputs, which are often not available from palaeodata. The empirical Osnabrück Biosphere Model (OBM) needs as input only 3 environmental parameters, easily derivable from pollen data. We adapted it to reconstruct the past terrestrial carbon storage from palaeodata. Sensitivity experiments performed by uniformly decreasing the mean annual temperature, average annual precipitation and/or $\mathrm{CO}_{2}$ concentration suggest that temperature and $\mathrm{CO}_{2}$ concentration affect the carbon storage more than does precipitation. The use of the only palaeodata available at a global scale shows that only a weakening of $\mathrm{CO}_{2}$ fertilization must be invoked to reconstruct the Last Glacial Maximum (LGM) carbon storage, which is an intermediate situation between the no-fertilization effect assumed by previous studies and the fertilization effect based on modernist empirical equations. The terrestrial carbon storage in the Northern Hemisphere for this period ranged from 910 to $1270 \mathrm{Pg}$, which represents an increase of 330 to $710 \mathrm{Pg}$ (a planetary increase of 470 to $1014 \mathrm{Pg}$ from the LGM to the present). This result is similar to our previous reconstruction and agrees broadly with the values estimated on the basis of $0.32 \%$ change obtained for global deep ocean $\delta^{13} \mathrm{C}$.
\end{abstract}

KEY WORDS: Terrestrial carbon storage $\cdot$ Biosphere model Palaeodata $\cdot$ Sensitivity experiment

\section{INTRODUCTION}

Studies of Antarctic ice cores have shown that the atmospheric concentration of $\mathrm{CO}_{2}$ during the Last Glacial Maximum (LGM) was $\sim 80$ ppmv (parts per million by volume) lower than the $\sim 280$ ppmv value of the pre-industrial period (Barnola et al. 1987). Biogeochemical processes that can modulate atmospheric $\mathrm{CO}_{2}$ concentration and the ocean-atmosphere carbon distribution have been explained in 2 different ways. The first model invokes a greater biological pump efficiency which involves greater sinking fluxes of organic carbon relative to upwelling of total $\mathrm{CO}_{2}$ (Broecker 1982, Volk \& Hoffert 1985j. The second model invokes alkalinity mechanisms which increase the concentration of $\left(\mathrm{CO}_{3}\right)^{2-}$ in glacial surface waters (Broecker \&
Peng 1989). Both models emphasize changes in $\delta^{13} \mathrm{C}$ of atmospheric $\mathrm{CO}_{2}$ between glacial and interglacial conditions. Marino et al. (1992) attribute isotopically light glacial atmospheric $\mathrm{CO}_{2}$ to a combination of factors including not only decreased productivity of the polar ocean but also reduced terrestrial biomass. Leuenberger et al. (1992) presented analyses of past carbon isotope composition of atmospheric $\mathrm{CO}_{2}$ from Antarctic ice; they also considered change in land biomass among the factors producing observed changes in atmospheric $\delta^{13} \mathrm{C}$. The hypothesis that less carbon was stored on the continents at the LGM was first formulated by Shackleton (1977), based on studies of the $\delta^{13} \mathrm{C}$ changes of benthic foraminifera in the equatorial Pacific. A further estimate of the mean $\delta^{13} \mathrm{C}$ content of the global ocean during the LGM, $0.32 \%$ lower than 
today, suggests there has been a 400 to $500 \mathrm{Pg}$ postglacial increase in the level of terrestrial carbon storage (Duplessy et al. 1988)

A great effort has been made to reconstruct the LGM terrestrial carbon budget. Simulations using atmospheric general circulation models (AGCMs) and various bioclimatic approaches yielded estimates for postLGM increases varying from $\pm 50 \mathrm{Pg}$ (Prentice \& Fung 1990) to $300 \mathrm{Pg}$ (Friedlingstein et al. 1992). A 300 to $700 \mathrm{Pg}$ range was recently obtained by Prentice et al. (in press), who used a global biome model (Prentice et al. 1992) derived from modern climate data (Leemans \& Cramer 1991), and the Hamburg AGCM simulations for the LGM and for today. The first estimate of postLGM increase based on land data, $1350 \mathrm{Pg}$, was given by Adams et al. (1990), who used continental palaeodata to produce a global map of LGM vegetation. A second estimate of terrestrial carbon storage was produced by Van Campo et al. (1993) using modern and LGM CLIMAP (Climate/Long Range Investigation Mapping and Prediction) compilations of both land and sea surface conditions. This new estimate indicates an increase of $715 \mathrm{Pg}$ (range 430 to $930 \mathrm{Pg}$ ) from the LGM to the present, which is more consistent with both the Prentice et al. (in press) modelling results and the ocean-based approach.

All the available model-or data-based estimates suffer severe limitations. They imply not only an equilibrium state between the vegetation, soil and climate, but also carbon densities for each ecosystem similar to modern values. Possible low-fertilization effects of low atmospheric $\mathrm{CO}_{2}$ concentration on the net primary production cannot be taken into account. Therefore, the combined use of palaeodata (Peterson et al. 1979, CLIMAP Project Members 1981, Frenzel et al. 1992) and of a biosphere carbon cycle model is required to reconstruct the dynamics of vegetation and soil carbon storage under changing global boundary conditions.

On the basis of the underlying processes of photosynthesis, respiration, transpiration, nitrogen cycling and carbon-nitrogen feedbacks, several terrestrial biogeochemical models have been recently developed to estimate the dynamics of terrestrial ecosystem production, biomass and soil organic matter at regional and global scales (Raich et al. 1991, McGuire et al. 1992, Melillo et al. 1993, Parton et al. 1993, Potter et al. 1993). But these process-based terrestrial biogeochemical models are difficult to use for investigating the glacial terrestrial carbon budget, because: (1) the complexity of interactions among terrestrial biogeochemical processes during the glacial-interglacial is poorly understood, and (2) few data sets are available to parameterize these models. The Osnabrück Biosphere Model (OBM) (Esser 1987, 1991) contains more empirical relationships than process-based equations, but needs only a few input parameters, which can be easily calculated from the available palaeodata. Moreover, it improves estimates of the carbon density of the various ecosystems. For these reasons, it has been used to estimate past terrestrial carbon dynamics in response to past climatic changes (Peng et al. 1994, Esser \& Lautenschlager 1993).

We present here an adapted version of the OBM developed by Esser (1987, 1991), which considers the $\mathrm{CO}_{2}$ fertilization effect. LGM terrestrial carbon is estimated from temperature, precipitation and ecosystem distribution provided by palaeodata and not by AGCM simulation as in Esser \& Lautenschlager (1993). Our results are compared with the CLIMAP-data-based estimate of Van Campo et al. (1993) and the AGCM simulation of Esser \& Lautenschlager (1993) at the Northern Hemisphere scale.

\section{MODEL AND DATA}

The Osnabrück Biosphere Model. We use a version of the OBM adapted to a $0.5^{\circ} \times 0.5^{\circ}$ grid. The model calculates the carbon fluxes and pools of the terrestrial biosphere depending on mean annual temperature, total annual precipitation and the atmospheric $\mathrm{CO}_{2}$ concentration. A detailed description of the model construction and a discussion of its ability to be applied to present conditions can be found in the original papers. Here we mainly highlight some important points and modifications introduced in this study.

The OBM model includes herbaceous and woody live biomass, litter from herbaceous and woody material, and soil organic carbon. The carbon fluxes are net primary production (NPP), allocation of assimilates to the compartment of live biomass, litter production, litter decomposition, soil organic carbon production, and soil organic carbon decomposition.

The NPP, which is the rate at which the vegetation in an ecosystem fixes carbon from the atmosphere (gross primary productivity) minus the rate at which it returns carbon to the atmosphere (plant respiration), represents the net carbon input from the atmosphere into the biosphere. The NPP calculated by OBM is an equilibrium prediction. The model assumes that vegetation changes in response to climatic change have been completed. The productivity share of the potential vegetation is basically limited either by temperature or precipitation and can be estimated by the MIAMI model (Lieth 1975), which is calibrated on 52 sites from North America, the Caribbean, Western Europe, Africa and Asia; it is modified by soil fertility $\left(F_{\text {soil }}\right)$ and by the $\mathrm{CO}_{2}$ fertilization effect $\left(F_{\mathrm{CO}_{2}}\right)$ (Esser 1991)

The $\mathrm{CO}_{2}$ fertilization effect is very important for understanding the glacial biospheric carbon budget. 
The $\mathrm{CO}_{2}$ fertilization factor, $F_{\mathrm{CO}_{2}}$ represents the influence of the entire complex of ecological effects of atmospheric $\mathrm{CO}_{2}$ concentration; it depends on the atmospheric $\mathrm{CO}_{2}$ concentration $\left(\mathrm{CO}_{2}\right)$ and soil fertility $\left(F_{\text {sol }}\right)$. The $\mathrm{CO}_{2}$ fertilization effect as described by Esser (1991, Eq. 31.5) can be reliably used in the case of modern higher $\mathrm{CO}_{2}$ concentrations, but the extrapolation of this equation to lower glacial $\mathrm{CO}_{2}$ concentrations is still speculative. In consequence, we consider 2 basic scenarios to examine the $\mathrm{CO}_{2}$ fertilization effect on terrestrial carbon storage at the LGM as in Esser \& Lautenschlager (1993).

In the OBM, the vegetation biomass is calculated by an empirical relationship between NPP and mean stand age of vegetation. Mean stand age is derived from DATAVW (a few gaps are filled using the method of ranking) (Esser 1984), and represents approximately the average turnover time of the vegetation. Litter production and decomposition, and soil organic carbon production and decomposition, are functions of mean annual temperature, total annual precipitation, atmospheric $\mathrm{CO}_{2}$ concentration, soil fertility, and vegetation types.

To estimate the potential carbon storage in vegetation, in litter and in soil pools, we do not take into account the land-use effect. The losses of dissolved and particulate organic carbon through leaching or deposition are generally negligible (Schlesinger \& Melack 1981, Schlesinger 1985).

Model inputs. The $\mathrm{CO}_{2}$ concentration of the atmosphere was set to a value of 280 ppmv for the pre-industrial period (present), and to 200 ppmv for the LGM, in agreement with the $\mathrm{CO}_{2}$ measurements from the Vostok ice core (Barnola et al. 1987). The sea level reduction for the LGM was assumed to be $-130 \mathrm{~m}$ (CLIMAP Project Members 1976), leading to a continental area of 18.71 million $\mathrm{km}^{2}$ for the Northern Hemisphere. Given that the atmosphere acts as an unlimited carbon source to fill the pools, we calculated the initial values for each pool using a fixed atmosphere $\mathrm{CO}_{2}$ concentration. The pre-run procedure indicated that $1500 \mathrm{yr}$ were needed to stabilize the large soil pools and prevent model drift in the continued model run.

The input data sets of the model were mean annual temperature, total annual precipitation, potential vegetation types and soil types at each grid cell.

The IIASA climatic database (Leemans \& Cramer 1991) provides mean annual temperature $\left(\mathrm{T}_{0 \mathrm{k}}\right)$ and total annual precipitation $\left(\mathrm{P}_{0 \mathrm{k}}\right)$ for a grid of $0.5^{\circ} \times 0.5^{\circ}$. We considered 17 vegetation types (Table 1 ) defined as in the biome model of Prentice et al. (1992). The mean stand age of each biome and the factor needed to calculate the proportion of herbaceous and woody production were taken from Esser (1991, Table 31.6)

The soil data (Zobler 1986) were based on a soil map of the world (FAO-UNESCO 1974) given for a $1^{\circ} \times 1^{\circ}$ grid. The soil units of this map were interpolated at the $0.5^{\circ} \times 0.5^{\circ}$ gridpoints as required by the model. The soil fertility factor, $F_{\text {soil }}$, was derived by comparing the measured NPP of the soil with NPP calculated from climate only (Esser 1991). The soil types not given in Table 31.4 in Esser (1991) were assumed to have an $F_{\text {soil }}$ of 1 (McGuire et al. 1993).

We limited our study to the Northern Hemisphere, where the input data needed were available for the LGM. The Northern Hemisphere represents about $70 \%$ of global terrestrial carbon storage (Van Campo et al. 1993) and thus plays a large role in the global carbon budget. The boreal forest represents the largest reservoir of soil carbon and is second, behind broadleaf humid forests, in vegetation carbon storage (Lashof 1989). Tans et al. (1990) hypothesized that mid-latitude ecosystems of the Northern Hemisphere are accumulating carbon at an annual rate of 2.0 to $3.4 \mathrm{Pg}$

\section{PRESENT CARBON STORAGE IN THE NORTHERN HEMISPHERE}

The latitudinal distribution of the total carbon storage in the Northern Hemisphere (Fig. 1) shows that the

Table 1. The 17 biomes as defined by Prentice et al. (1992). The mean stand age of each biome and the biomass share factor for herbaceous production, $H_{h}$, were derived from Esser (1991, Table 31.6). (The biomass share factor for woody production is simply calculated as $1-H_{h}$ )

\begin{tabular}{llrl}
\hline Code & Biome & $\begin{array}{r}\text { Mean stand age } \\
(\text { yr })\end{array}$ & $H_{h}$ \\
& & 5 & 0.48 \\
TUND & Tundra & 1 & 1.0 \\
COGS & Cool grass/shrub & 10 & 0.7 \\
WTUN & Wooded tundra & 100 & 0.34 \\
TAIG & Taiga forest & 100 & 0.36 \\
CLMX & Cold mixed forest & 100 & 0.38 \\
CLDE & Cold deciduous forest & 130 & 0.29 \\
COMX & Cool mixed forest & 130 & 0.29 \\
COCO & Cool conifer forest & 130 & 0.29 \\
WAMX & Warm/evergreen mixed forest & 150 & 0.38 \\
WADE & Temperate deciduous & 20 & 0.4 \\
XEWS & Xerophytic woods/shrub & 15 & 0.85 \\
SEDE & Semidesert & 5 & 0.98 \\
SAWO & Tropical savanna & 80 & 0.4 \\
TRDF & Tropical dry forest & 5 & 0.85 \\
HODE & Hot desert & 1 & 1.0 \\
WAGS & Warm grass/shrub & 200 & 0.37 \\
EQEG & Tropical rain/seasonal forest & & \\
\hline
\end{tabular}




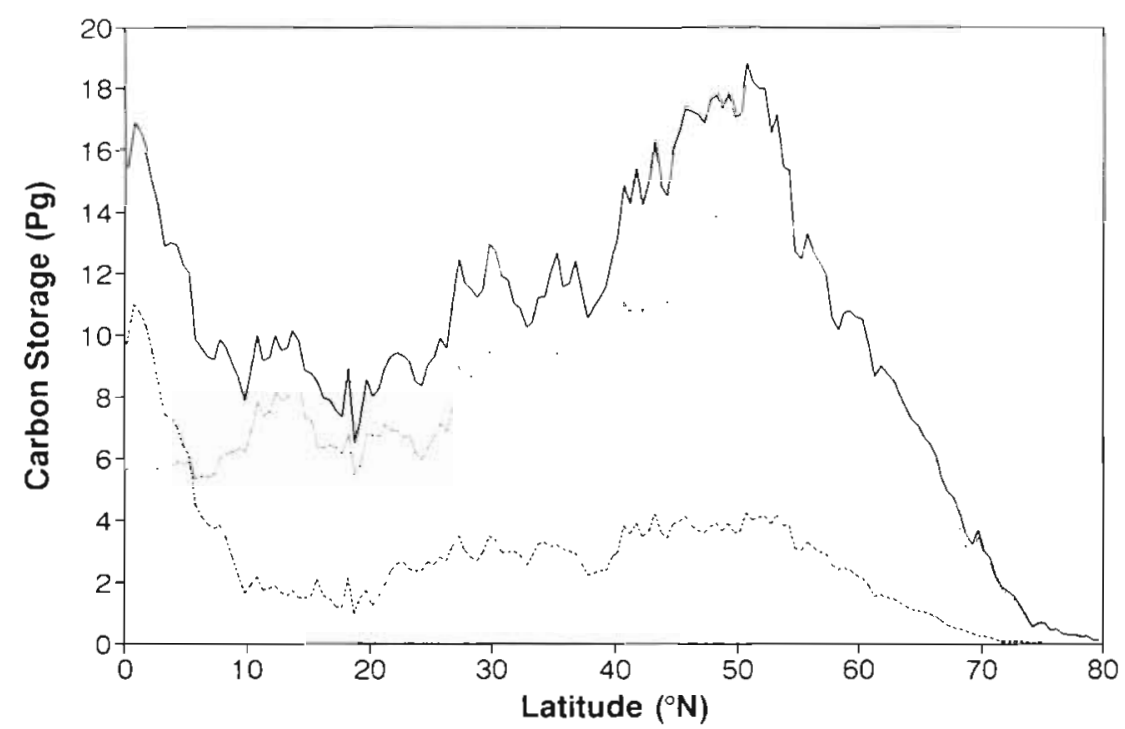

Total Carbon
Soil Carbon
….... Vegetation Carbon
Fig. 1. Present-day zonally averaged distribution of total carbon, vegetation carbon, and soil carbon by $0.5^{\circ}$ latitude band highest amount is stored at about $52^{\circ} \mathrm{N}$, where climate and nutrients are favorable for temperate and boreal forests on a large continental area. This result is similar to that of Van Campo et al. (1993).

The maximum vegetation carbon storage occurs in the equatorial humid forest with high biomass; the lowest vegetation carbon storage is found between $10^{\circ}$ and $20^{\circ} \mathrm{N}$, corresponding to open vegetation and desert, and between $65^{\circ}$ and $80^{\circ} \mathrm{N}$, corresponding to tundra-steppe and polar desert.
The soil carbon storage increases continuously from $20^{\circ}$ to $50^{\circ} \mathrm{N}$ due to a gradual temperature decrease. The largest soil carbon storage appears at about $45^{\circ}$ to $53^{\circ} \mathrm{N}$, corresponding to temperate and boreal forests (with high carbon storage in peat bog soil). Tropical forest soil contains less carbon than other forest types, because high temperature and sufficient precipitation amplify the soil respiration.

The distributions of area and of carbon storage for each ecosystem are shown in Fig. 2. The higher carbon

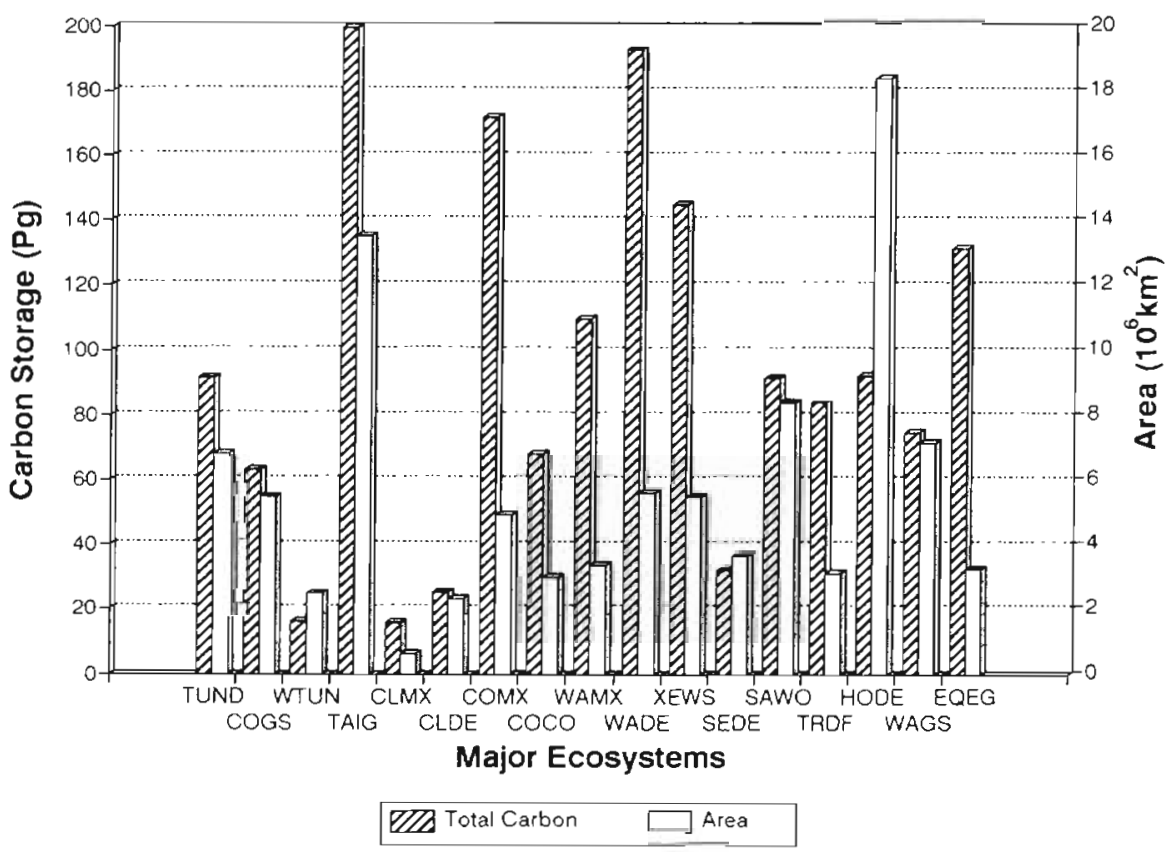

Fig. 2. Present-day distribution of total carbon storage and area among the major ecosystems. See Table 1 for ecosystem abbreviations 
Fig. 3. Zonally averaged values of total carbon storage for temperature variations of $0^{\circ} \mathrm{C}$ (present-day situation), $-2^{\circ} \mathrm{C}$ and $-5^{\circ} \mathrm{C}$, by latitude

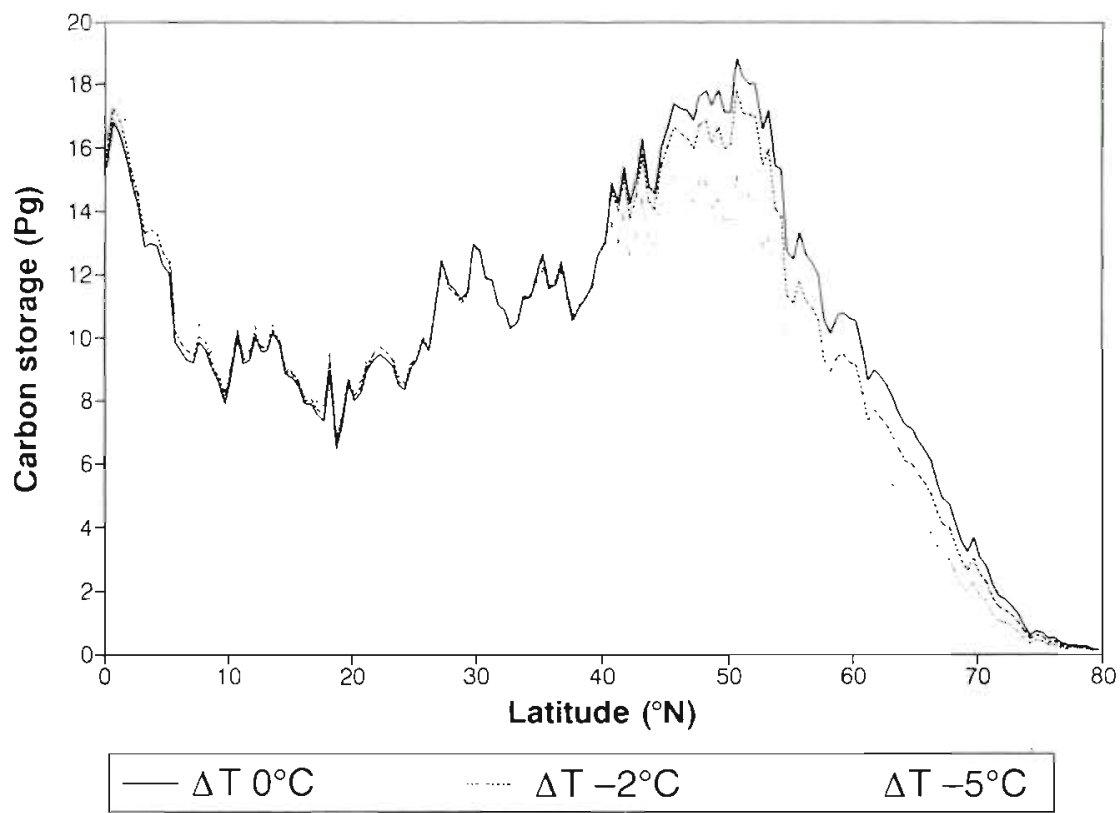

storages occur respectively in taiga (TAIG) with $199 \mathrm{Pg}$, temperate deciduous forest (WADE) with $193 \mathrm{Pg}$ and cool mixed forest (COMX) with $172 \mathrm{Pg}$, due to their larger area. The lower carbon storages are found in the cool mixed forest (CLMX) with $16 \mathrm{Pg}$, wooded tundra (WTUN) with $16 \mathrm{Pg}$ and cool deciduous forest (CLDE) with $25 \mathrm{Pg}$, due to their smaller area. The hot desert (HODE) occupies the largest area with $18 \times 10^{6} \mathrm{~km}^{2}$, but it has a low carbon storage (about $92 \mathrm{Pg}$ ).

Total carbon storage in the Northern Hemisphere (see Table 3) was $1604 \mathrm{Pg}$ for the studied area of $101 \times$ $10^{6} \mathrm{~km}^{2}$, with $431 \mathrm{Pg}$ in the vegetation and $1173 \mathrm{Pg}$ in the soil. As carbon storage in the Northern Hemisphere is about $70 \%$ of the global carbon storage (Van Campo et al. 1993), this result broadly agrees with calculations by Esser \& Lautenschlager (1993) and is higher than estimations by Schlesinger (1977), Atjay et al. (1979) and Olson et al. (1985) for global terrestrial ecosystems with land-use disturbances (about $560 \mathrm{Pg}$ in vegetation and 1500 to $1600 \mathrm{Pg}$ in soil).

\section{SENSITIVITY EXPERIMENTS}

In order to examine how changes in temperature, precipitation and $\mathrm{CO}_{2}$ concentration would affect carbon storage, several sensitivity studies were carried out with the OBM by altering the 3 factors individually (Esser 1987, McGuire et al. in press).

The atmospheric $\mathrm{CO}_{2}$ concentration was about 200 ppmv at the LGM (Barnola et al. 1987). The palaeoclimatic data (CLIMAP Project Members 1976 , Peterson et al. 1979) suggest that the unglaciated land surface at 18000 yr BP was generally colder and drier than at present. The differences in temperature were from -1 to $-12^{\circ} \mathrm{C}$ and even larger, while precipitation differences were more variable. The mean difference was about $-5^{\circ} \mathrm{C}$ for temperature and $-30 \%$ for precipitation. We studied the overall effect of climate on the carbon storage by successively decreasing: (1) temperature at each gridpoint, by $2^{\circ} \mathrm{C}$ and $5{ }^{\circ} \mathrm{C}$; (2) precipitation, by $10 \%$ and $30 \%$; and (3) atmospheric $\mathrm{CO}_{2}$ concentration, by 30 ppmv and 80 ppmv.

\section{Sensitivity to temperature}

Temperature was decreased successively by $2^{\circ} \mathrm{C}$ and $5^{\circ} \mathrm{C}$ while precipitation and $\mathrm{CO}_{2}$ concentration were maintained at modern values. Fig. 3 shows that the carbon storage increased from $0^{\circ}$ to $30^{\circ} \mathrm{N}$ and decreased from $30^{\circ}$ to $80^{\circ} \mathrm{N}$ due to the ice sheet and the open vegetation extensions. Cooling reduces soil respiration more than vegetation photosynthesis between $0^{\circ}$ and $30^{\circ} \mathrm{N}$. In contrast, vegetation photosynthesis decreased more than soil respiration between $30^{\circ}$ and $80^{\circ} \mathrm{N}$. The range of response was evidently larger for the $5^{\circ} \mathrm{C}$ decrease than for the $2^{\circ} \mathrm{C}$ decrease; the change in carbon storage was especially dramatic in the high-latitude regions, where temperature is a strong limiting factor. The total carbon storage (Table 2) decreased by about $3.3 \%$ for $\Delta \mathrm{T}=2{ }^{\circ} \mathrm{C}$ (28 $\mathrm{Pg}$ in vegetation and $25 \mathrm{Pg}$ in soil), and by $9.2 \%$ for $\Delta \mathrm{T}=5^{\circ} \mathrm{C}$ (74 Pg in vegetation, $73 \mathrm{Pg}$ in soil). As the LGM at high and middle latitudes was much cooler than simulated in these experiments, it is likely that the LGM carbon 
storage was reduced by more than $20 \%$ due to temperature alone.

\section{Sensitivity to precipitation}

The total carbon storage was slightly altered by precipitation decreases of 10 and $30 \%$. Table 2 shows that the total carbon storage was decreased by $0.7 \%$ and $1.8 \%$ respectively. In fact, vegetation carbon storage decreased by 21 and $72 \mathrm{Pg}$ respectively, but soil carbon increased by 11 and $42 \mathrm{Pg}$, because in these complex ecological interactions, the decrease in soil moisture limits soil metabolic activity, which might lead to a reduction of the soil heterotrophic respiration. At the scale of the Northern Hemisphere, the net effect is negative, although it is slightly positive between $58^{\circ}$ and $75^{\circ} \mathrm{N}$ (Fig. 4).

\section{Sensitivity to $\mathrm{CO}_{2}$ concentration}

Fig. 5 and Table 2 show that decreases in $\mathrm{CO}_{2}$ concentration by 30 and 80 ppmv had a strong effect on carbon storage, leading to reductions of $8.1 \%$ (36 Pg in vegetation, 92 $\mathrm{Pg}$ in soil) and $24.9 \%$ (109 $\mathrm{Pg}$ in vegetation, $290 \mathrm{Pg}$ in soil) respectively. In the OBM calculations, NPP is affected directly by $F_{\mathrm{CO}_{2}}$ which, as described above, depends on $\mathrm{CO}_{2}$ concentration and soil fertility. This explains why $\mathrm{CO}_{2}$ concentration is the most important limiting factor in the changes of carbon storage.
Table 2. Vegetation, soil, and total carbon storage (vegetation $C+$ soil $C$ ) for various experiments with the OBM. Sensitivity experiments were performed by simply decreasing the values of temperature $\left(-2^{\circ} \mathrm{C}\right.$ and $\left.-5^{\circ} \mathrm{C}\right)$, precipitation $(-10 \%$ and $-30 \%)$, and $\mathrm{CO}_{2}$ concentration $(-30$ ppmv and -80 pppmv) with respect to the present climate dataset. Cumulative effects represent the effects of decreasing temperature, precipitation and $\mathrm{CO}_{2}$ concentration. Values in parentheses are the differences between the results and present-day values. Values are given in Pg carbon

\begin{tabular}{|lcccc|}
\hline Sensitivity experiment & Veg. C & Soil C & Total C & Change \\
\hline Present climate & 431 & 1172 & 1604 & \\
Temperature $-2^{\circ} \mathrm{C}$ & 403 & 1148 & 1551 & \\
& $(-28)$ & $(-25)$ & $(-53)$ & $-3.3 \%$ \\
Temperature $-5^{\circ} \mathrm{C}$ & 357 & 1099 & 1456 & \\
& $(-74)$ & $(-73)$ & $(-147)$ & $-9.2 \%$ \\
Precipitation $-10 \%$ & 410 & 1183 & 1593 & \\
& $(-21)$ & $(+11)$ & $(-10)$ & $-0.7 \%$ \\
Precipitation $-30 \%$ & 359 & 1215 & 1574 & \\
& $(-72)$ & $(+42)$ & $(-30)$ & $-1.8 \%$ \\
$\mathrm{CO}_{2}$ concentration & 395 & 1080 & 1475 & \\
-30 ppmv & $(-36)$ & $(-92)$ & $(-128)$ & $-8.1 \%$ \\
$\mathrm{CO}_{2}$ concentration & 322 & 883 & 1205 & \\
-80 ppmv & $(-109)$ & $(-290)$ & $(-399)$ & $-24.9 \%$ \\
$\mathrm{Cumlal}^{\circ}$ & 249 & 851 & 1100 & \\
$\left(-5^{\circ} \mathrm{C},-30 \%,-80 \mathrm{ppmv}\right)$ & $(-182)$ & $(-322)$ & $(-504)$ & $-31.4 \%$ \\
\hline
\end{tabular}

\section{Sensitivity to all 3 factors}

We examine now the cumulative effects of changes in temperature $\left(-5^{\circ} \mathrm{C}\right)$, precipitation $(-30 \%)$ and $\mathrm{CO}_{2}$ concentration ( -80 ppmv), as they should better reflect the LGM conditions.

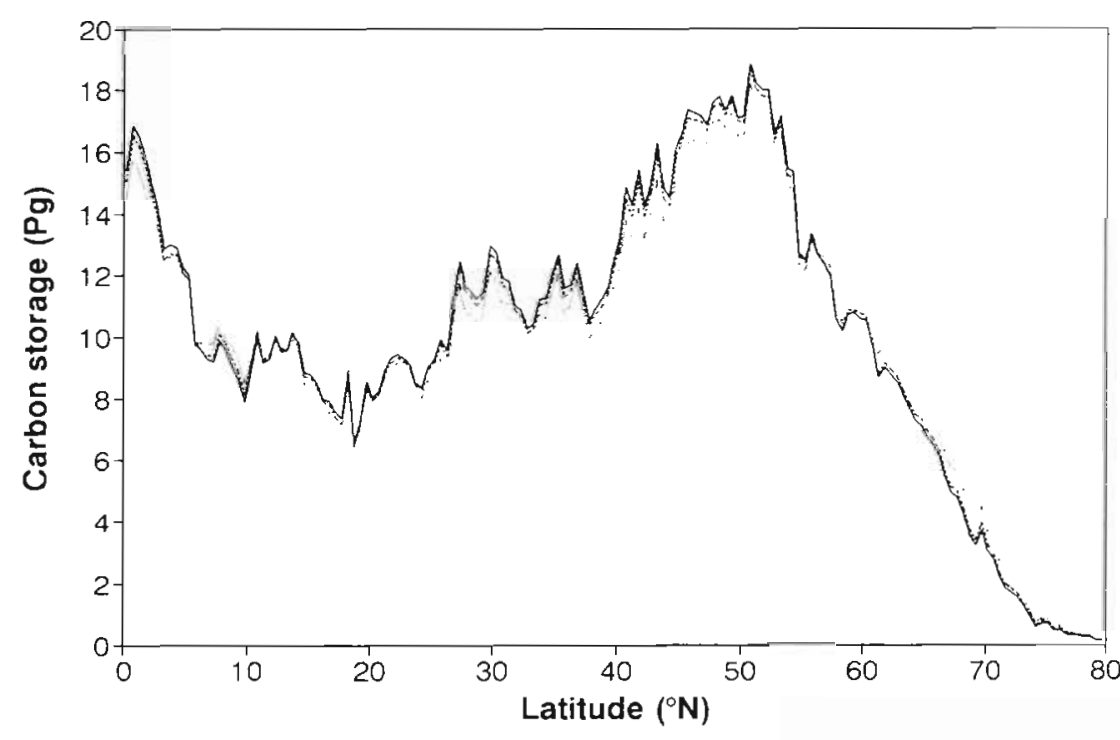

\begin{tabular}{|lc}
\hline $\mathrm{P} 0 \%$ & $\Delta \mathrm{P}-30 \%$ \\
\hline
\end{tabular}

Fig. 4. Zonally averaged values of total carbon storage for precipitation variations of $0 \%$ (present-day situation), $-10 \%$ and $-30 \%$, by latitude 
Fig. 5. Zonally averaged values of total carbon storage for several $\mathrm{CO}_{2}$ concentrations, by latitude. The value of $280 \mathrm{ppmv}$ represents the preindustrial $\mathrm{CO}_{2}$ concentration

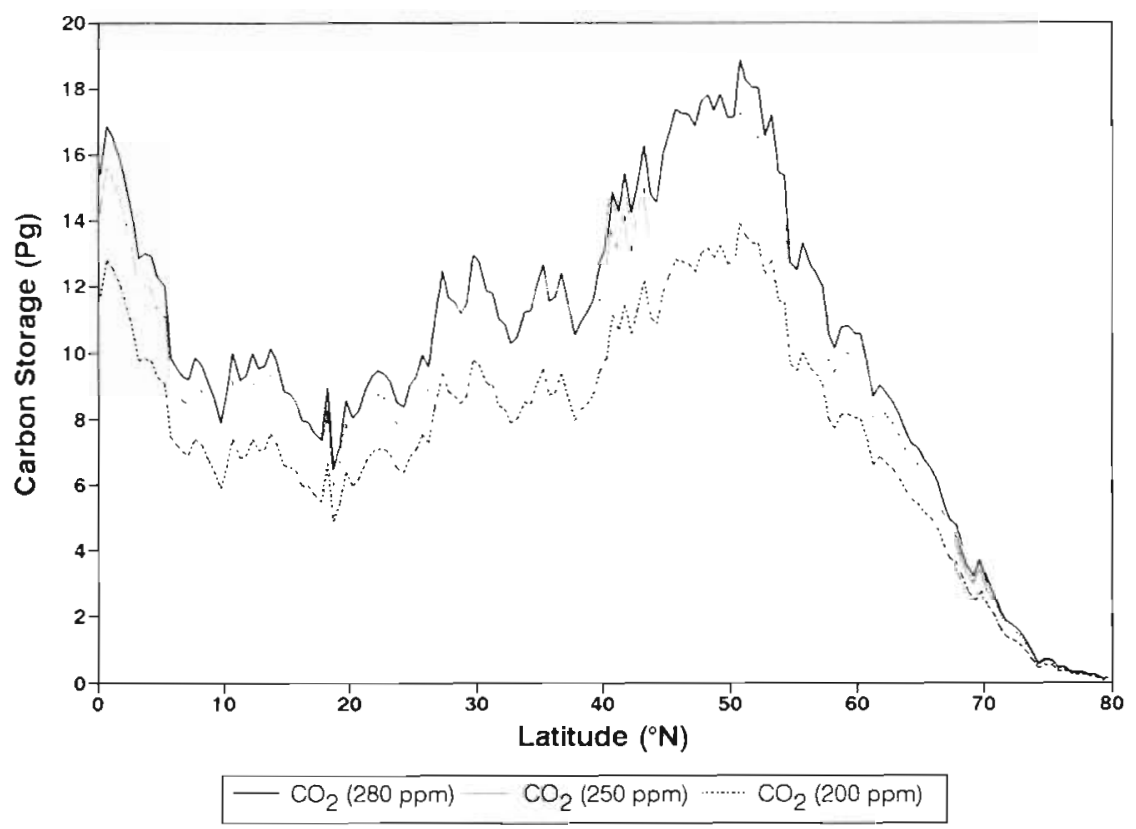

occurred at the middle latitudes during the LGM, these carbon storage values certainly represent an upper limit. This must be tested now with more realistic anomalies.

\section{A MORF REAIISTIC TEST FOP THE LGM IN THE NORTHERN HEMISPHERE}

Vegetation and climatic LGM palaeodata at each gridpoint are necessary to run the OBM, but very few data are available. On the one hand, the CLIMAP rethe more pronounced temperature decrease which

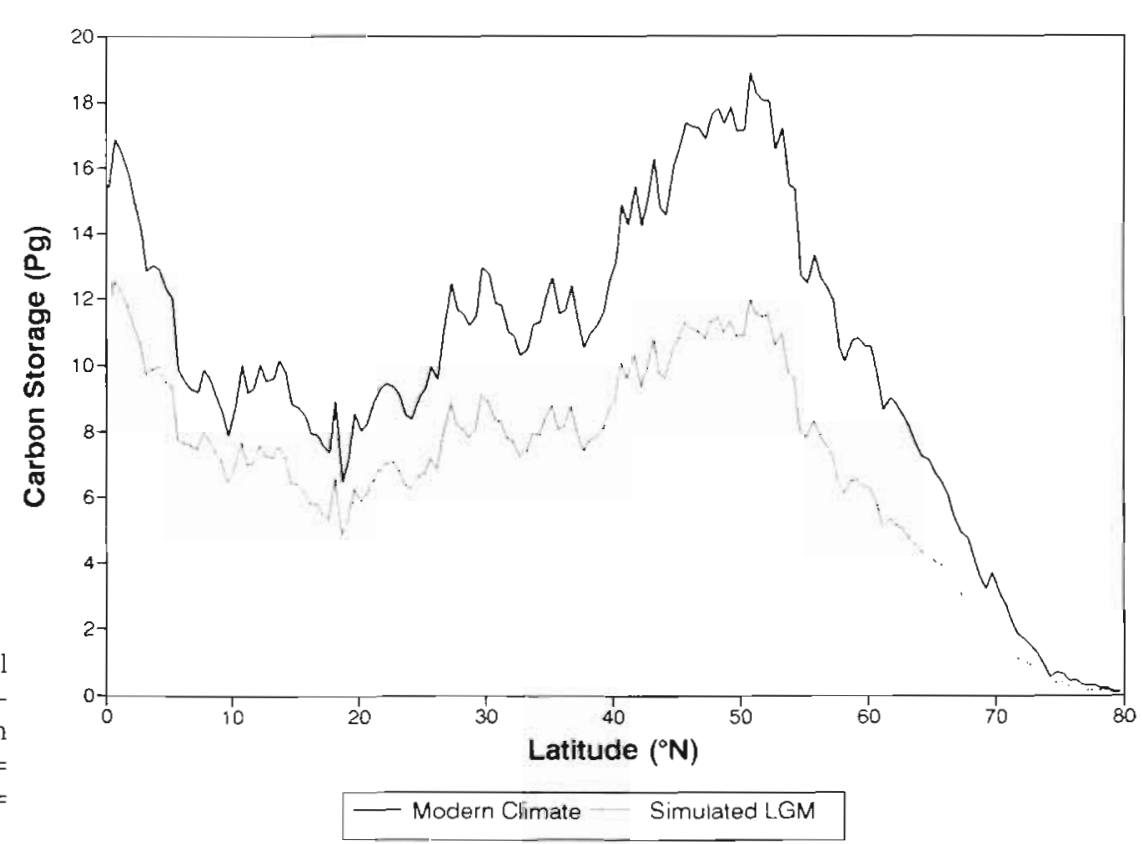

Fig. 6. Zonally averaged values of total carbon storage, by latitude, for the present-day situation and for variations in several factors (simulated LGM: $\triangle \mathrm{T}=$ $-5^{\circ} \mathrm{C}, \Delta \mathrm{P}=-30 \%, \mathrm{CO}_{2}$ concentration $=$ 200 ppmv) 
constructions of the earth's surface at the LGM (CLIMAP Project Members 1981) provide main vegetation types, but not the mean annual temperature or total annual precipitation on the continents. On the other hand, the atlas of Frenzel et al. (1992) provides these 3 necessary variables, although the data, methods and stratigraphy on which the reconstructions are based are not clearly shown and their reliability is not indicated. However, the LGM period, with a vegetation dominated by steppes and tundra, is certainly more reliably reconstructed than any other periods presented in this atlas. In the absence of more recent reconstructions based on global palaeoecological databases, we used this atlas to perform an additional test of the OBM.

\section{Climate reconstruction}

The anomalies of the mean annual temperature $\left(\Delta \mathrm{T}_{18 \mathrm{k}}\right)$, and total annual precipitation $\left(\Delta \mathrm{P}_{18 \mathrm{k}}\right)$ for the LGM were digitized at the $0.5^{\circ} \times 0.5^{\circ}$ gridpoints from the atlas of Frenzel et al. (1992). The mean annual temperature $\left(T_{18 k}\right)$, and total annual precipitation $\left(P_{18 k}\right)$ were obtained by adjusting the IIASA modern climate (Leemans \& Cramer 1991) database values (Tok, POk) using the gridded anomalies:

$$
\begin{aligned}
& T_{18 k}=T_{0 k}+T_{18 k} \\
& P_{18 k}=P_{0 k}+P_{18 k}
\end{aligned}
$$

\section{Vegetation reconstruction}

The map of ecosystems proposed by Grichuk (Frenzel et al. 1992) provides the distribution of 9 main vegetation types which were digitized at the $0.5^{\circ} \times 0.5^{\circ}$ grid level for the LGM. They correspond to a subset of the biomes of Prentice (Table 1): (1) preglacial tundra vegetation (TUND), (2) preglacial steppe vegetation (COGS), (3) boreal forest (TAIG), (4) broad-leaved and mixed conifer forest (COMX), (5) steppe and desert vegetation (SEDE), (6) subtropical savanna vegetation (SAWO), (7) tropical forests (TRDF), (8) tropical desert steppe vegetation (HODE), (9) high mountain (alpine) vegetation (TUND). The mean stand age (years) of each vegetation type and the factor needed to calculate the proportion of herbaceous and woody production were derived from Esser (1991, Table 31.6) assuming that these values are the same as those of the present for corresponding vegetation types.

\section{Soil data}

Because of the lack of soil information for the LGM, we simply used the same soil map as for the present and the same fertility factor $\left(F_{\text {soll }}\right)$, assuming that $F_{\text {soil }}$ stays constant under modern climatic conditions and LGM boundary conditions. We have no reason to think that such an assumption has important consequences for carbon storage, since $F_{\text {soil }}$ values are in fact empirical correction factors which are defined as the ratio of the NPP measured on a given soil type to the NPP calculated from the MIAMI model (Lieth 1975).

\section{Estimation of carbon storage}

Because the potential fertilization effect of $\mathrm{CO}_{2}$ is not fully understood and certainly depends on factors not considered here, we chose 2 basic scenarios for estimating LGM carbon storage, as in Esser \& Lautenschlager (1993): Scenario 1, $\mathrm{CO}_{2}$ fertilization effect considered; Scenario 2, no $\mathrm{CO}_{2}$ fertilization effect.

Scenario 1. At 200 ppmv $\mathrm{CO}_{2}$, the totai carbon storage was estimated to be about $910 \mathrm{Pg}(193 \mathrm{Pg}$ in vegetation, $717 \mathrm{Pg}$ in soil). This result indicates a $694 \mathrm{Pg}$ increase in vegetation and soil since the LGM in the Northern Hemisphere, which is much more than the carbon storage increase (400 to $500 \mathrm{Pg}$ ) obtained for the whole globe based on ocean $\delta^{13} \mathrm{C}$. Thus, the OBM certainly overestimates the $\mathrm{CO}_{2}$ fertilization reduction during the LGM (Esser \& Lautenschlager 1993).

Scenario 2. Neglecting the $\mathrm{CO}_{2}$ fertilization effect gave carbon storage estimates of about $1276 \mathrm{Pg}$ (251 $\mathrm{Pg}$ in vegetation, $1025 \mathrm{Pg}$ in soil), which implies a $327 \mathrm{Pg}$ increase in vegetation and soil since the LGM in the Northern Hemisphere, due solely to climate improving. This result is closer to the estimates of Van Campo et al. (1993). Considering that the carbon storage of the Northern. Hemisphere contributed about $70 \%$ of the global carbon budget at the LGM as calculated by Van Campo et al. (1993), this result agrees with the 400 to $500 \mathrm{Pg}$ post-glacial increase in global terrestrial carbon storage estimated by deep ocean $\delta^{13} \mathrm{C}$ (Duplessy et al. 1988). This scenario shares with all the previous approaches (Adams et al. 1990, Prentice \& Fung 1990, Friedlingstein et al. 1992, Van Campo et al. 1993, Prentice et al. in press) the assumption that the modern carbon densities for each ecosystem can be extrapolated to the LGM.

\section{DISCUSSION AND CONCLUSION}

The sensitivity experiments suggest that temperature and atmospheric $\mathrm{CO}_{2}$ concentration have important effects on terrestrial carbon storage. The $\mathrm{CO}_{2}$ fertilization factor, which depends on the $\mathrm{CO}_{2}$ concentration and soil fertility, involves complex processes. Although the $\mathrm{CO}_{2}$ fertilization effect as modified by 
Esser (1991) is reliable for the modern $\mathrm{CO}_{2}$ concentration, extrapolation to the lower glacial $\mathrm{CO}_{2}$ concentration (200 ppmv) at the LGM is still highly speculative and probably unreliable (Esser \& Lautenschlager 1993)

The carbon storage of Scenario 1 is close to the low carbon storage estimates of Van Campo et al. (1993), whereas the result of Scenario 2 is most similar to their median estimate (Table 3). In fact, large parts of North America, Europe and Asia were covered by herbaceous vegetation (Melillo et al. 1990). C4 plants were more extensive than C3 plants during the LGM, for several reasons: $\mathrm{C} 4$ plants are not only more competitive (Patterson \& Flint 1990) but also have a higher net photosynthesis (Taiz \& Zeiger 1991) than C3 plants at low $\mathrm{CO}_{2}$ concentrations. Considering $\mathrm{C} 4$ plants' physiological and ecological mechanisms and metabolism, the NPP of vegetation dominated by $\mathrm{C} 4$ plants should have been less reduced at the LGM than that constituted mainly by $\mathrm{C} 3$ plants. The carbon storage at the LGM should thus have been greater than suggested by Scenario 1 (Esser \& Lautenschlager 1993). But, although the result of Scenario 2 is more similar to that of Van Campo et al. (1993), neglecting $\mathrm{CO}_{2}$ fertilization is not realistic either. Rather, the reality must have been between these 2 extremes. A realistic estimate of carbon storage in the Northern Hemisphere at the LGM, therefore, is between 910 and $1270 \mathrm{Pg}$.

If we comnare the results of our 2 scenarios with the estimates of Esser \& Lautenschlager (1993) using the previous assumption that the carbon storage of the Northern Hemisphere contributed about $70 \%$ of the global carbon budget during the LGM, as calculated by Van Campo et al. (1993), we find (Table 3) that the carbon storage levels under 2 scenarios of Esser \& Lautenschlager (in press) are higher than those reported both in this study and in Van Campo et al. (1993). Especially the results of Scenario 2 of Esser \& Lautenschlager (1993) (i.e. 19.2\% increase from LGM to present) are in disagreement with both the global deep ocean $\delta^{13} \mathrm{C}$ data and our Scenario 2 result (i.e. $20.6 \%$ decrease). The main reason for this is that the AGCM model simulations generally overestimate precipitation in tropical and subtropical regions at the LGM, leading not only to a great reduction in the areas simulated as deserts and an extension of other biome types, but also to an increase in carbon content (Van Campo et al. 1993).

In Fig. 7, a comparison of the distribution of carbon storage among several major ecosystems is made between Scenario 2 of this study and the Van Campo et al. (1993) study (both without $\mathrm{CO}_{2}$ fertilization effects). The figure shows that the greatest differences occur for the tundra and the tropical dry forest ecosystems, but in opposite directions. For the latter ecosystem, the

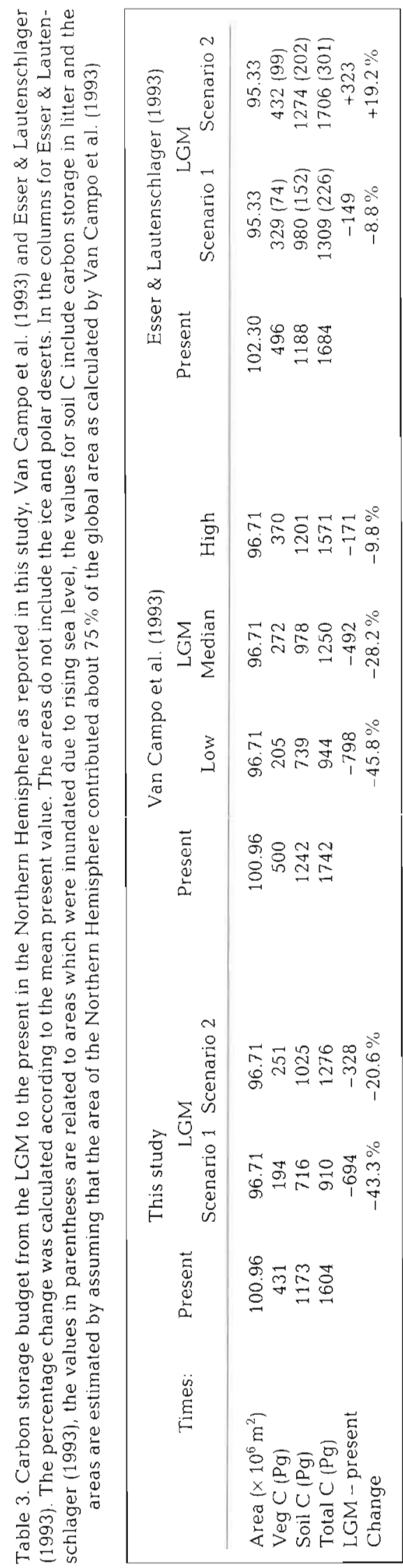


difference is due to the difference in the area reconstructed (Fig. 7a, TRDF). For the tundra, Olson et al. (1985) ascribe a higher carbon density than estimated by the OBM, which is likely unable to simulate the high carbon content in tundra soil.

The OBM is inherently limitated, because it is a regression-based empirical model which hardly takes into account possible geophysical feedback between decomposition and productivity (McGuire et al. 1993). Moreover, because of the lack of systematic soil infor-

\section{a}

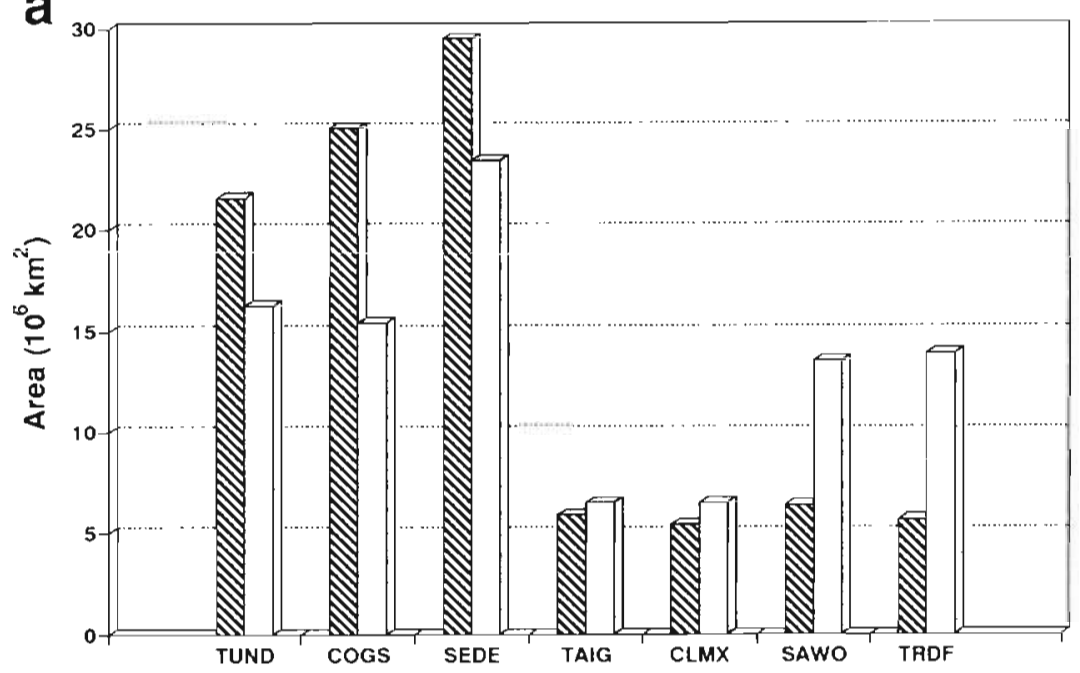

b

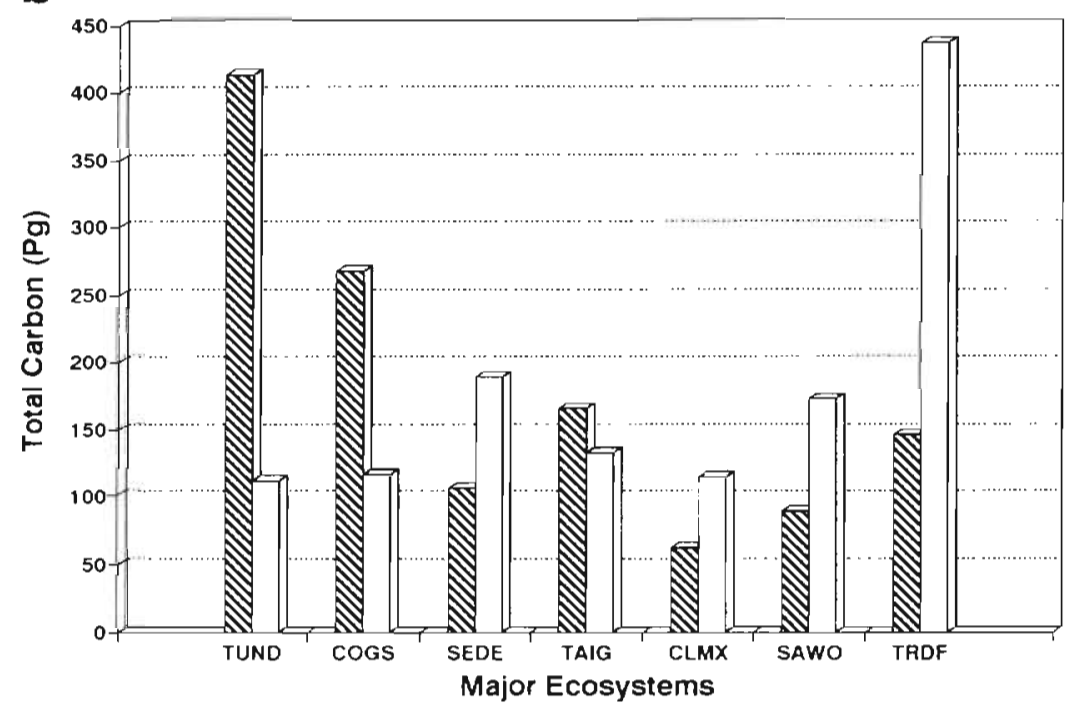

MVan Campo et al. (1993) $\square$ OBM (Scenario 2)

Fig. 7 Comparison between the results of Van Campo et al. (1993) and those of Scenario 2 of this study (no $\mathrm{CO}_{2}$ fertilization), showing (a) area, and (b) total carbon storage of the major ecosystems at the LGM (see Table 1 for ecosystem codes) Here TRDF includes EQEG; SEDE includes HODE: CLMX includes COMX WADE and CLDE. The other ecosystems are not represented at the LGM mation for the LGM, it is probably simplistic to assume the same soil fertility factors from the LGM to the present. A further limitation lies in our insufficient knowledge of palaeoclimate and palaeovegetation distribution at the LGM. The alternative is to couple a biosphere model to an AGCM simulation, as was done by Esser \& Lautenschlager (1993), but this approach also has limitations (low resolution, rough parameterization and approximate boundary conditions) and must be validated by data, which justifies our approach.

In summary, our sensitivity experiments suggest that the changes in temperature and in $\mathrm{CO}_{2}$ concentration affect carbon storage more than changes in precipitation. It appears that a weakening of $\mathrm{CO}_{2}$ fertilization must be invoked to obtain a realistic estimate of LGM carbon storage. At the scale of the Northern Hemisphere, our reconstruction (i.e. low terrestrial carbon storage at the LGM combined with low $\mathrm{CO}_{2}$ concentration) implies that the terrestrial biosphere acted as a sink for the $\mathrm{CO}_{2}$ released by the ocean during the post-glacial atmospheric $\mathrm{CO}_{2}$ increase. The size of this sink, based on our reconstruction from the Osnabrück Biosphere Model and palaeodata, agrees broadly with the values estimated on the basis of $0.32 \%$ change obtained for global deep ocean $\delta^{13} \mathrm{C}$.

Acknowledgements. The EEC EPOCH Programme and the Programme Environment (Groupe Ecosystemes-PIGB) of the Centre National de la Recherche Scientifique supported this research. We thank G. Esser who kindly provided the low resolution version of the Osnabrück Biosphere Model. Further, we thank J. C. Duplessy for his comments on an earlier draft of the manuscript.

\section{LJTERATURE CITED}

Adams JM, Faure $H$, Faure-Denard L, McGlade JM, Woodward FI (1990) Increases in terrestrial carbon storage from the Last Glacial Maximum to the present. Nature 348:711-714

Atjay GL, Ketner P, Duvignead P (1979) Terrestrial primary production and phytomass. In: Bolin B, Degens E, Kempe $S$, Ketner P (eds) The global carbon cycle. SCOPE 13. Wiley, Chichester, p $129-182$

Barnola JM, Raynaud D, Korotkevitch YS, Lorius C (1987) Vostok ice core pro- 
vides 160,000 years record of atmospheric $\mathrm{CO}_{2}$. Nature 329:408-414

Broecker WS (1982) Glacial to interglacial changes in ocean chemistry. Prog Oceanogr 11:151-197

Broecker WS, Peng TH (1989) The cause of the glacial to interglacial atmospheric $\mathrm{CO}_{2}$ change a polar alkalinity hypothesis. Global biogeochem Cycles 3:215-239

CLIMAP Project Members (1976) The surface of the Ice-Age earth. Science 191:1131-1136

CLIMAP Project Members (1981) Seasonal reconstruction of the earth's surface at the Last Glacial Maximum. Map Chart Series MC-36, 1-18. Geological Society of America

Duplessy JC, Shackleton NJ, Fairbanks RG, Labeyrie L, Oppo D, Kallel N (1988) Deepwater source variations during the last climatic cycle and their impact on the global deepwater circulation. Paleoceanography 3:343-360

Esser G (1984) The significance of biospheric carbon pools and fluxes for the atmospheric $\mathrm{CO}_{2}$ : a proposed model structure. Prog Biometeorol 3:253-294

Esser G (1987) Sensitivity of global carbon pools and fluxes to human and potential climatic impacts. Tellus 39B:245-260

Esser G (1991) Osnabrück Biosphere Model: structure, construction, results. In: Esser G, Overdick D (eds) Modern ecology: basic and applied aspects. Elsevier, Amsterdam, p $679-709$

Esser G, Lautenschlager M (1993) Estimating the change of carbon in the terrestrial biosphere from $18,000 \mathrm{BP}$ to present using a carbon cycle model. Environ Pollut 83:45-53

FAO-UNESCO (1974) Soll map of the world, 1:5000000, Vols. I-X. UNESCO, Paris

Frenzel B, Pécsi M, Velichko AA (eds) (1992) Atlas of paleoclimates and paleoenvironments of the northern hemisphere, Late-Pleistocene-Holocene. Geographical Research Institute, Hungarian Academy of Sciences, Budapest

Friedlingstein C, Delire C, Muller JF, Gérard JC (1992) The climate induced variation of the continental biosphere: a model simulation of the last glacial maximum. Geophys Res Lett 19:897-900

Lashof DA (1989) The dynamic greenhouse: feedback processes that may influence future concentrations of atmospheric trace gases and climatic change. Clim Change 14: $213-242$

Leemans R, Cramer WP (1991) The IIASA database for mean monthly values of temperature, precipitation, and cloudiness on a global terrestrial grid. Rep IIASA Research RR91-18. International Institute for Applied System Analysis, Laxenburg

Leuenberger M, Siegenthaler U, Langway C (1992) Carbon isotope composition of atmospheric $\mathrm{CO}_{2}$ during the last ice age from an Antarctic ice core. Nature 375:488-490

Lieth $\mathrm{H}$ (1975) Modeling the primary production of the world. In: Lieth $\mathrm{H}$, Whittaker $\mathrm{RH}$ (eds) Primary productivity of the biosphere. Springer-Verlag, New York, p. 237-263

Marino BD, McElroy MB, Salawitch RJ, Spaulding WG (1992) Glacial-to-interglacial variations in the carbon isotopic composition of atmospheric $\mathrm{CO}_{2}$. Nature 357:461-465

McGuire AD, Joyce LA, Kicklighter DW, Melillo JM, Esser G, Vorosmarty CJ (1993) Productivity response of climax temperate forests to elevated temperature and carbon dioxide: a North American comparison between two global models. Clim Change 24:287-310

McGuire AD, Melillo JM, Joyce LA, Kicklighter DW, Grace AL, Moore B III, Vorosmárty CJ (1992) Interaction between carbon and nitrogen dynamics in estimating net primary productivity for potential vegetation in North America. Global biogeochem Cycles 6:101-124
Melillo JM, Callaghan TV, Woodward FI, Salati E, Sinha SK (1990) Effect on ecosystems. In: Houghton JT, Jenkins GJ, Ephraums JJ (eds) Climate change: the IPCC scientific assessment. Cambridge University Press, Cambridge, p $283-310$

Melillo JM, MCGuire AD, Kicklighter DW, Moore B III, Vorosmarty CJ, Schloss AL (1993) Global clumate change and terrestrial net primary production. Nature 363:234-240

Olson JS, Watts JA, Allison LJ (1985) Major world ecosystem complexes ranked by carbon in live vegetation, a database. NPD-017, Carbon Dioxide Information Center, Oak Ridge National Laboratory, Oak Ridge, TN

Parton WJ, Scurlock JMO, Ojima DS, Gilmanov TG, Scholes RJ, Schimel DS, Kirchner T, Menaut JC, Seastedt T, Garcia Moya E, Apinan Kamnalrut, Kinyamario Jl (1993) Observations and modeling of biomass and soil organic matter dynamics for the grassland biome worldwide. Global biogeochem Cycles 4:785-809

Patterson DT, Flint EP (1990) Implications of increasing carbon dioxide and climate change for plant communites and competition in natural and managed ecosystems. In: Kimball et al. (eds) Impact of carbon dioxide, trace gases, and climate change on global agriculture. ASA Spec. Publ. Number 53, American Society of Agronomy, p 83-110

Peng CH, Guiot J, Van Campo E, Cheddadi R (1994) The vegetation carbon storage variation in Europe since $6000 \mathrm{BP}$ : reconstruction from pollen. J Biogeogr 21:19-31

Peterson GM, Webb T III, Kutzbach JE, Van Der Hammen T, Wijmstra TA, Street FA (1979). The continental record of evvironmental conditions at 18000 yr B.P.: an initial evaluation: Quat Res 12:47-82

Potter CS, Randerson JT, Field CB, Matson PA, Vitousek PM, Mooney HA, Klooster SA (1993) Terrestrial ecosystem production: a process model based on global satellite and surface data. Global biogeochem Cycles 4:811-841

Prentice IC, Cramer W. Harrison SP, Leemans R, Monserud RA, Solomon AM (1992) A global biome model based on plant physiology and dominance, soil properties and climate. J Biogeogr 19:117-134

Prentice IC, Sykes MT, Lautenschlager M, Harrison SP, Denissenko O, Bartlein PJ (in press) Modelling the increase in terrestrial carbon storage after the last glacial maximum. Global Ecol Biogeogr Lett

Prentice KC, Fung IY (1990) The sensitivity of terrestrial carbon storage to climate change. Nature 346:48-51

Raich JW, Rastetter EB, Melillo JM, Kicklighter DW, Steudler PA, Peterson BJ, Grace AL, Moore B III, Vorosmarty CJ (1991) Potential net primary productivity in South America: application of a global model. Ecol Appl 1:399-429

Schlesinger WH (1977) Carbon balance in terrestria] detritus. A Rev Ecol Syst 8:51-81

Schlesinger WH (1985) The formation of caliche in soil of the Mojave Desert, California. Geochim Cosmochim Acta 49: $57-66$

Schlesinger WH, Melack JM (1981) Transport of organic carbon in the world's rivers. Tellus 33:172-187

Shackleton NJ (1977) Carbon 13 in Uvigerina: tropical rain forest history and the equatorial Pacific carbonate dissolution cycles. In: Anderson RLN, Malahoff A (eds) The fate of fossil fuel $\mathrm{CO}_{2}$ in the oceans. Plenum, New York, $\mathrm{p}$ $401-427$

Taiz L, Zeiger E (1991) Plant physiology. The Benjamin Cummings Publ Co, Redwood City, CA

Tans PP, Fung IY, Takahashi T (1990) Observational constraints on the global atmospheric $\mathrm{CO}_{2}$ budget. Science 247:1431-1438

Van Campo E, Guiot J, Peng CH (1993) A data-based re- 
appraisal of the terrestrial carbon budget at the Last Glacial Maximum. Global planet Change 8:189-201

Volk T, Hoffert ML (1985). The carbon and atmospheric $\mathrm{CO}_{2}$ : natural variation archean to present. In: Sundquist ET

Editor: G. Esser, Gießen, Germany
Broecker WW (eds) Geophysical Monographs 32. Amencan Geophysical Union, Washington, DC, p 99-110

Zobler L (1986) A world soil file for global climate modeling. Rep. NASA GISS, TM 87802, New York

Manuscript first received: June 16, 1994

Revised version accepted: September 22, 1994 